Bond University

Research Repository

\title{
Financial Stability After the Global Financial Crisis: Globalisation, Nationalism and the Potential Demise of a Rules-Based Order
}

Farrar, John H; Parsons, Louise

Published in:

Scholarship, Practice and Education in Comparative Law

DOI:

10.1007/978-981-13-9246-7_6

Licence:

Other

Link to output in Bond University research repository.

Recommended citation(APA):

Farrar, J. H., \& Parsons, L. (2019). Financial Stability After the Global Financial Crisis: Globalisation, Nationalism and the Potential Demise of a Rules-Based Order. In J. H. Farrar, V. I. Lo, \& B. C. Goh (Eds.), Scholarship, Practice and Education in Comparative Law: A Festschrift in Honour of Mary Hiscock (pp. 81-111). Springer. https://doi.org/10.1007/978-981-13-9246-7_6

\section{General rights}

Copyright and moral rights for the publications made accessible in the public portal are retained by the authors and/or other copyright owners and it is a condition of accessing publications that users recognise and abide by the legal requirements associated with these rights.

For more information, or if you believe that this document breaches copyright, please contact the Bond University research repository coordinator. 


\title{
Financial Stability After the Global Financial Crisis: Globalisation, Nationalism and the Potential Demise of a Rules- Based Order
}

\author{
Professor John H Farrar \\ Emeritus Professor, Bond University \\ Honorary Professor of Law, University of Auckland and University of Waikato \\ Louise Parsons \\ Assistant Professor, Bond University
}

We are very pleased to contribute to this festschrift for our friend and colleague Prof Mary Hiscock to honour her life time's work in comparative and international law. Both of us have had a long association with Mary, in the case of John, one going back to the 1980s. We have both enjoyed interesting and stimulating conversations with Mary on various aspects of comparative and international law, and this chapter was inspired by our shared interests and friendships.

\section{Introduction}

This paper examines the relationship between globalisation after the Global Financial Crisis (GFC) and financial stability, and in particular the effect that recent changes in the global order may have on financial stability and its regulatory frameworks. ${ }^{1}$ To do so, this paper first provides background on the nature of the concept of financial stability, and the difficulties that the nature of the concept financial stability itself poses for its regulatory frameworks. The paper then considers the history of globalisation and its impact on financial markets, and the disruptive effect that the GFC and Eurocrisis had on financial stability and but also on globalisation. It considers whether intended solutions and responses to the GFC have, contrary to what was intended, rather contributed to instability. ${ }^{2}$ This analysis takes place against the background of history of the Bretton Woods system and Washington Consensus. It focusses on the rules-based order that has prevailed in international relations and that has also impacted on regulatory frameworks for financial stability through the activities of international organisations and groups. ${ }^{3}$ The paper then points to a possible pivot point that

\footnotetext{
${ }^{1}$ This paper is based on, and further develops the ideas expressed in a conference paper in honour of Prof David Mayes. See Farrar, J.H. and Parsons, L. (2018).

${ }^{2}$ Most of the crisis was dealt with by central banks, that are national institutions, attempting to deal with a globalized world. The result of individual and collective action by central banks was massive injections of liquidity into financial markets which on its own is now a potential new cause of instability.

${ }^{3}$ Such as, for example, the G20, the IMF and the FSB.
} 
may have been reached, leading to not just the undermining of globalisation through increased nationalism ${ }^{4}$ and even populism, ${ }^{5}$ but also to threats for financial stability, and financial stability regulatory frameworks. The paper explains how the seeds of nationalism and populism ${ }^{6}$ can, ironically, be found in globalisation ${ }^{7}$ and the Washington Consensus themselves. ${ }^{8}$ The results of the rise of nationalism and populism include threats to financial stability and the legal frameworks for financial stability. This is significant, because for markets to function well, a well-functioning legal framework is needed. This paper concludes that the demise of the rules-based order may also impact financial stability regulatory frameworks, and financial stability itself. ${ }^{9}$

\section{Financial stability - a significant but elusive concept}

The problems of achieving financial stability have not yet been resolved and may never be. In fact, financial instability and financial crises are possibly inevitable. The World Economic Forum has recently identified some current challenges that threaten financial stability, ${ }^{10}$ including unsustainable asset prices, elevated indebtedness particularly in China and continuing strains in the global financial system. Added to these are the impact of climate change, ${ }^{11}$ automation and digitalisation and the build-up of mercantilist, protectionist policies. In the background are rising geopolitical tensions. How these threats to financial stability are countered by the responsible regulators can have far-reaching consequences.

Central banks are now widely regarded as being responsible for achieving and maintaining financial stability. ${ }^{12}$ The concept of financial stability itself and its meaning, however, does

\footnotetext{
${ }^{4}$ See Roubini, N. (2014). Roubini describes the new nationalism as taking on different economic forms, namely 'follows: trade barriers, asset protection, reaction against foreign direct investment, policies favouring domestic workers and firms, anti-immigration measures, state capitalism, and resource nationalism'. He noted that 'populist, anti-globalisation, anti-immigration, and in some cases outright racist and antisemitic parties are on the rise.'

${ }^{5}$ Populism can be described as follows: 'Populism rejects a deep suspicion of the prevailing establishment; that this establishment in the view of most populists does not just rule in the common good but conspires against the people; and that the people, however defined, are the true repositories of the soul of the nation'. See Cox, M. (2018).

${ }^{6}$ Populism should not be vilified or seen as 'evil'. See Cox, M. (2017) and Cox, M. (2018). It is useful to consider that populism can refer to three very distinct things. First, it can be seen to refer to a particular regime, typically popular in the short-term but unsustainable in the long term, secondly, it can refer to the definition group of persons who provide legitimacy to policies, and thirdly, it can be seen to be a particular style of leadership. See Fukuyama, F. (2018).

${ }^{7}$ According to Cox, M. (2017) this can also be seen as hyperglobalisation. See also Funke, M. and Trebesch, C. (2017). They note that 'financial crises of the past 30 years have been a catalyst of right-wing populist politics'. ${ }^{8}$ According to Cox, M. (2017) 'populism in its modern iteration is a search for meaning in what Tony Giddens earlier termed a 'runaway world' of globalisation'.

${ }^{9}$ It is worth noting that the phrase 'rules-based order' is not necessarily without problems. Ungerer notes: 'The phrase 'rules-based international order' is a broad church under which many sins can be accommodated. And most countries will continue to take a selective approach to international rules. The fact is, like Orwell's Napoleon, some 'rules' matter more than others.' Ungerer, C. (2018), p 11.

${ }^{10}$ World Economic Forum (2018).

${ }^{11}$ See Collins, A. (2019). The World Economic Forum suggests that the world may be sleepwalking into a global crisis.

${ }^{12}$ See Goodhart, C.A.E. (2010)
} 
not enjoy the same consensus. The concept remains elusive, imprecise and hard to define. The definition of financial stability proposed by the Reserve Bank of Australia, is similar to those proposed by other central banks and academics, and can serve as a useful working definition. The Reserve Bank of Australia describes financial stability as follows: ${ }^{13}$

A stable financial system is one in which financial intermediaries, markets and market infrastructure facilitate the smooth flow of funds between savers and investors and, by doing so, help promote growth in economic activity. Conversely, financial instability is a material disruption to this intermediation process with potentially damaging implications for the real economy.

There are a number of reasons for the lack of a precise definition of 'financial stability'. Firstly, it may not be considered necessary, as the concept is intuitively understood and prima facie clear. ${ }^{14}$ Secondly, the concept may be influenced by historical and geographical factors, leading to the impossibility of adopting a single definition, and thirdly, there are different theories underpinning it. Nevertheless, it is important to attempt to define it more precisely. This is for reasons of legitimacy, strategy and transparency and accountability in the mandate of central banks and/or other regulators tasked with financial stability. In this paper it also elucidates the roles of national regulators in a broader international context.

\section{A. 'Finance' and 'Stability'}

Any approach to define financial stability should take account of both components of the concept: financial (or finance) and stability.

\section{Finance needs a measure of instability}

Financial stability is fundamentally a bit of a misnomer. Finance depends on some measure of 'instability'. Finance has as its heart lending and borrowing, and provides the mechanism facilitating the use of surplus funds of 'savers' by 'investors' who have access to opportunities to advance positive economic outcomes. There has to be surplus on the one hand and deficit on the other for finance to be possible.

Stability is the second component of the concept financial stability and also defies clear definition. It is often easier to identify instability, and financial stability is therefore frequently defined with reference to its opposite. Financial stability is to some extent what the philosopher JL Austin in Sense and Sensibilia ${ }^{15}$ called a 'trouser word situation'. In other words, it is arguable that the opposite - financial instability - wears the proverbial trousers, that is, controls the definition. ${ }^{16}$ The negative characteristics of the most recent financial crisis could for example be included in the definition as aspects of a positive state of financial stability. This approach 'limits perception of financial stability strictly to the lack of [a] financial

\footnotetext{
${ }^{13}$ Reserve Bank of Australia (2019).

${ }^{14}$ It is widely used in the media and even academic literature without definition or analysis.

${ }^{15}$ Austin, J.L. (1962) The Bank of England used the term in 1994 to denote those of its objectives that were not to do with price stability or the efficient working of the financial system. See Allen, W.A. and Wood, G. (2006).

${ }^{16}$ See also Allen, W.A. and Wood, G. (2006).
} 
crisis'. ${ }^{17}$ This would not always be the case, because 'asset bubbles can build up and systemic risk can accumulate [even] in the absence of visible signs of ... [a] crisis'. ${ }^{18}$

\section{Defining stability by its opposite, instability}

The approach of defining financial stability through its opposite, although useful, is not without its problems. Although 'defining episodes of financial instability' ${ }^{19}$ is a good starting point for a definition of financial stability, it is not sufficient ${ }^{20}$ or ideal. ${ }^{21}$ Implicit in using financial instability as a starting point is that the pursuit of financial stability then becomes the avoidance of financial instability. ${ }^{22}$ If policy objectives were simply geared at avoiding financial instability, then policy decisions, analyses, and analytical frameworks could become biased, and both private and social benefits of finance could be sacrificed. ${ }^{23}$ Therefore, if avoiding financial instability were however a general policy objective, economic growth may be detrimentally affected, and one of the key social and private benefits of finance - the creation of economic growth - can thereby be lost.

Formulating a definition of financial stability that is not based on the opposite (i.e. financial instability) has a number of advantages. Schinasi points out that such an approach does not limit the concept of financial stability to a single quantitative indicator, ${ }^{24}$ as for example the existence of a specific event of instability. Further, a definition not based on instability is forward-looking, ${ }^{25}$ and would not necessarily be influenced by the most recent financial crisis. A definition not based on a description of financial instability also recognizes that 'policies aimed at financial stability often involve a trade-off between resilience and efficiency', ${ }^{26}$ meaning that at times, systems may be efficient (e.g. lead to growth) through certain failures (i.e. a lack of resilience). At other times, resilience should be prioritised over efficiency. Further, Schinasi points out that a definition of financial stability that is not premised on financial instability has the benefit that 'policy requirements for financial stability may be time inconsistent' ${ }^{27}$ Such an approach 'may serve additional practical purposes, including leaving open the possibility of assessing whether the private and social benefits of finance can be increased further'. ${ }^{28}$

There is however no single approach or accepted view as to what should constitute financial stability. The Financial Stability Board and the G20 have for example had no difficulty in

\footnotetext{
${ }^{17}$ Smaga, P. (2013), pp 14-15.

18 Ibid.

${ }^{19}$ Laker, J.F. (1999), p 2. See also Allen, W.A. and Wood, G. (2006).

${ }^{20}$ Laker, J.F. (1999), p 2.

${ }^{21}$ See Schinasi, G.J. (2004).

22 Ibid.

${ }^{23}$ In essence, if the objective were to avoid financial instability, then decisions would have to be aimed at riskavoidance. If there were, for example, evidence of rapid economic growth in a particular area of the economy, and it appeared as if it could potentially create financial instability, then regulators may decide to move against such a potential instability. This type of rapid economic growth could however simply be a situation that is a temporary bubble in asset prices and one that would normally be corrected by market forces.

${ }^{24}$ Schinasi, (2004), above n 21, p. 11.

25 Ibid.

$26 \mathrm{Ibid}$

27 See Schinasi, (2004), above n 21, p.12.

${ }^{28}$ See Schinasi, (2004) above n 21. p 3. See also Schinasi, G.J. (2010).
} 
providing a policy agenda and even a regulatory agenda for financial stability not just of the G20 countries, but the broader international financial system. It appears that an intuitive common-sense interpretation has sufficed. ${ }^{29}$

\section{Financial stability and equilibrium}

It may be useful to compare financial stability with equilibrium. The relationship of financial stability to equilibrium in financial markets has led to some academic analysis. ${ }^{30}$ The question can be asked whether the achievement of stability is even possible through market forces or government intervention in financial markets. ${ }^{31}$ 'It is difficult to define what is meant by equilibrium in finance, in part because equilibrium prices and resource allocations today depend on expectations of future outcomes, while expectations can be highly volatile if not unstable'.32

\section{Narrow and broad interpretations of 'financial stability'}

Perhaps more significant from the perspective of the regulators of financial stability, is how broadly or narrowly the concept is interpreted. Broad versus narrow interpretations of the concept financial stability are particularly important from the perspective of governments seeking to build regulatory frameworks for the safeguarding of financial stability. Approaches to definitions of financial stability in practice can employ broader or narrower views. The broader view takes account of social and political factors, institutions outside of the financial sector, and considers broader public policy implications. At its broadest, financial stability can be equated to national economic prosperity and growth. Economic welfare and full employment are for example part of the general mandate of the RBA, ${ }^{33}$ and may be indicative of a broad approach to financial stability definitions by the Australian government. The narrow view limits notions of financial stability to stability in the financial system only, including its markets, institutions, processes, systems and technology. Some commentators limit the scope of financial stability to stability in the financial system or financial industry itself (i.e. to the exclusion of the broader economy and other industries); others consider financial stability to include the overall stability of the national economy. ${ }^{34}$ The definition of financial stability, and what is included in the ambit of financial stability mandates, are therefore fundamentally important, but not consistently given much (or any) consideration.

\section{B. Regulating financial stability}

The lack of financial stability definitions has not diminished efforts to regulate financial stability. In fact, financial stability mandates have been included in the founding legislation of regulators - such as the Bank of England or the South African Reserve Bank - even though no

\footnotetext{
${ }^{29}$ Hillary Allen however points to the need for some clarity in the definition of financial stability. See Allen, (2014).

${ }^{30}$ Equilibrium first occurred as a concept in Leon Walras's major writings in 1874. For scepticism about equilibrium in capitalised finance, see Hyman Minsky, (1986), p 250-253. See also Schinasi (2010).

${ }^{31}$ See Minsky (2010).

${ }^{32}$ Schinasi, (2004).

${ }^{33}$ Reserve Bank of Australia Act 1959 (Cth) s 10(2).

${ }^{34}$ See Schinasi, (2004).
} 
comprehensive definition of financial stability was provided. ${ }^{35}$ The scope of such mandates are therefore fundamentally unclear, as is what the regulator is ultimately responsible for.

Much of the regulatory frameworks for financial stability have however focussed on the known causes of financial instability, for example insufficient capital held by financial institutions. The regulation of financial stability at international level has taken place at the Bank for International Settlements, even before the GFC, and have been implemented internationally as part of the three Basel Accords. The adoption of the Basel Accords- which can be seen as some of the most successful implementation of internationally created 'soft law' ever - constitute voluntary state practice by the countries represented at that Basel Committee on Bank Supervision at the BIS, as well as other countries. ${ }^{36}$ It can be argued that the adoption of the Basel Accords internationally is based in pragmatism or commercial expediency, but the rigour with which the Accords have been implemented and their implementation monitored, reflect a fundamental respect for a rules-based order. ${ }^{37}$ Other international measures that impact financial stability, such as the FATF Recommendations to combat money laundering and terrorism financing, ${ }^{38}$ fall into the same category of internationally developed soft law that is broadly implemented, and reflect a rules-based order through the monitoring of their implementation.

Notwithstanding the scope of the definition of financial stability adopted (broad or narrow), it would be a mistake to limit causes of financial stability to the financial system in the strict sense, and financial sources. The international trade system which has existed in the World Trade Organisation has introduced stability in trade, with a positive effect on financial stability. Whilst stable trade relations may not directly lead to financial stability, trade disputes have most certainly negatively impacted financial stability. The WTO and FTA arrangements that are fundamentally rules-based systems, have significantly contributed to avoiding financial instability through their established mechanisms.

Regulating financial stability requires a strong rules-based system not least because of the interconnectedness of the financial system. Modern financial systems are ${ }^{39}$

structured as networks made by a constellation of diverse entities that, for a variety of reasons, are highly interdependent. This means that a problem in one node of the financial network can easily transmit instability to others and therefore endanger the entire financial system. Regulation plays a fundamental role in containing systemic risks.

We turn now to an examination of globalisation, and the nexus between globalisation and financial stability.

\footnotetext{
${ }^{35}$ See ss 1 and 4 of the Financial Sector Regulation Act 9 of 2017 South Africa, and s2A Bank of England Act 1998 UK.

${ }^{36}$ See Lupo-Pasini, F. (2017). His view is that national law will always take precedence and that international considerations will not trump national considerations in financial matters.

${ }^{37}$ The BIS for example reports to the G20 on the implementation of Basel III.

38 See FATF, (2012).

${ }^{39}$ Lupo-Pasini, F. (2017) above $\mathrm{n} 36$.
} 


\section{Globalisation - a paradigm}

\section{A. Globalisation defined}

Globalisation is not a government policy but rather a complex state of affairs, which has become something of a paradigm in law, economics and international relations. Usage of the word globalisation dates back to the 1960s and connotes internationalisation and, to some extent, standardisation. It is mainly thought of in economic terms, but can refer to social, political and other cultural matters. Some aspects of globalisation have been around for over three thousand years. For example, the Silk Road enabled international trade to take place between East and West. ${ }^{40}$ Globalisation can be defined as follows: ${ }^{41}$

Globalization involves economic integration; the transfer of policies across borders; the transmission of knowledge; cultural stability; the reproduction, relations, and discourses of power; it is a global process, a concept, a revolution, and "an establishment of the global market free from sociopolitical control.

There are many different definitions of globalisation, including more comprehensive definitions, ${ }^{42}$ and some demonstrate a particular bias. ${ }^{43}$ Professor Harry Arthurs, the distinguished Canadian academic, has referred to 'globalisation of the mind'. He argues that it 'involves a change in our social values and in our fundamental understandings about what role law does play and should play in society. Globalisation is, in other words, an ideology'. ${ }^{44}$ $\mathrm{He}$ argues that beneath this ideology lies a bedrock assumption that governments which interfere with the free flow of goods, services, capital and information (but not people) impair their capacity to maintain a dynamic economy. This reflects the importance of the economic dimension of globalisation, and also the so-called Washington Consensus (see below).

\section{B. Effects/consequences of globalisation}

Globalisation has had many positive outcomes. It has led to a transfer of production of goods to developing countries, providing employment and increased prosperity. It has led to less barriers for migration, particularly of skilled workers. There has been a proliferation of international institutions, increasing from 'a few hundred in 1950 to more than 7,000 today'. ${ }^{45}$ Through the "'embedding" [of] the global economy in a linked system of domestic regulation and global governance, the industrialized world was able to sustain an economic miracle', ${ }^{46}$ which has produced benefits to poorer, less developed nations. There are however negative aspects of globalisation too.

As a concept, globalisation can be said to have filled a gap in the policies of the Clinton Administration ${ }^{47}$ and it came to be identified substantially with US hegemony and the

\footnotetext{
${ }^{40}$ See Frankopan, P. (2015). See also Farrar, J.H. and Mayes, D. (2013).

${ }^{41}$ See Al-Rodhan (2006).

42 See UNESCO, (2017 for a detailed explanation of globalisation as a multi-dimensional process.

${ }^{43}$ Some definitions of globalisation for example are inherent criticisms of globalisation.

${ }^{44}$ Arthurs, H. (2009), p 632.

${ }^{45}$ Hale, T. and Held, D. (2017).

${ }^{46} \mathrm{Ibid}$.

${ }^{47}$ Farrar, J.H. and Mayes, D. (2013), above n 40, p 2.
} 
Washington Consensus after the end of the Cold War. ${ }^{48}$ Despite the apparent advantages of globalisation, ${ }^{49}$ the result was that the role of the State particularly in small countries became constrained by membership of the global community, which reduced their ability to choose domestic policies in the face of standards of international agreements, increased competition and a degree of convergence mandated by international markets, and credit rating agencies. ${ }^{50}$ There are winners and losers. This has led to redundancies in home countries.

\section{Globalisation and financial stability}

\section{A. Globalisation and Financial Markets}

Globalisation has resulted in an 'increasingly interconnected financial system', making the financial system a system and not just a collection of individual firms and markets. ${ }^{51}$ It has not only increased financial interconnections, but it has also facilitated economic advancement, and the propagation of systemic risk around the world. ${ }^{52}$

\section{B. Globalisation's benefits for financial stability}

Financial internationalisation was a strong theme in globalisation. Financial stability was therefore affected by the globalisation process. In fact, globalisation was intended to lead to many positive financial outcomes - and did achieve some of its goals

Globalisation has had a noticeable impact on financial stability, and in particular financial stability regulation. This is evident in the similarity displayed by legal frameworks in different countries. It was also evident in the factors leading to the GFC, and ironically in the resolution of the GFC and steps taken to prevent similar future crises.

Empirical evidence suggests that financial globalisation has a positive consequence ${ }^{53}$. In a 2017 World Bank Policy Research Paper investigating financial globalisation and market volatility from an empirical perspective, ${ }^{54}$ it was argued that financial globalisation reduced market volatility (measured by the volatility of stock returns) in tranquil times, and increased it in turbulent times. On average the first effect dominates, so financial globalisation overall leads to a decrease in market volatility. ${ }^{55}$ Financial instability events or causes however differ

\footnotetext{
48 Ibid.

${ }^{49}$ See Rodrik, D. (2018). Rodrik notes globalization has benefits to inter alia exporters, multinational companies, investors, and banks that could take advantage of larger markets. Rodrik also emphasised that poor countries also benefitted and in particularly China could rapidly transform agricultural and manufacturing operations, leading to growth and reduced poverty.

50 lbid.

${ }^{51}$ Berner, R. (2017).

52 Tissot, B. (2016), p.1.

${ }^{53}$ See Rodrik, D. (2018), above n 49.

${ }^{54}$ See Cordella, T. and Ospino Rojas, A. (2017). For the effect on emerging markets, see Obstfeld, M. (2015), in a working paper for the BIS. For a very interesting recent paper see Claessens, S. and Ayhan Kose, M. (2017) also for the BIS. For the interaction of real and financial assets see Rasmus, J. (2016).

55 Since this is based on stock market prices, one must question whether it would be true if it was possible to aggregate data from all 6 financial markets and to trace more closely the interconnections.
} 
from one crisis to next. At times instability has been created by problems in the property markets, as in the USA in the 1980s and 2000s, and Japan in the 1990s. At other times it has been stock markets that caused instability, as in 1929, 1987 and the tech bust of 2000. Sometimes it has been currency markets, as in the Asian financial crisis, ${ }^{56}$ that led to financial crises. Some financial crises, such as the GFC and Eurocrisis, for example, arise at least in part because of a globalisation of consequences of financial instability events. What started with a subprime mortgage crisis in a part of the economy of the US, created a global crisis, largely as a consequence of the interconnectedness of markets and institutions internationally, as well as the international operations of large complex financial institutions. However, many of the solutions and proactive measures developed after the GFC have been widely implemented, for example through the adoption of the Basel Accord.

Some of the safeguarding of financial stability through globalisation arises through the adoption of commensurable measures and regulations. There is some consistency in the international approaches to regulation of financial institutions, as well as in the regulatory frameworks of the regulators, and the overall regulatory architecture. An international 'best practice' can be said to have emerged, but the ideal toolkit and regulatory architecture are still up for debate. ${ }^{57}$

One of the key benefits from an increased financial openness and internationalisation, was the development of 'international financial rules', many of which have been widely adopted. The existence and adoption of these 'international financial rules' are interesting points to consider. There are no treaties, but simply agreements, and not legally binding agreements. Even so, the 'international financial rules', even if they are merely 'recommendations', are treated as if they are rules, and in fact do derive from treaty-like obligations. They have their origins in soft law. ${ }^{58}$

The origin of these 'international financial rules' can be traced back to before the GFC, but their development after the GFC is of particular interest in this paper. After the GFC, the G20 rose to be the key body where the discussion of financial stability measures could take place. During the GFC, the G20, which was originally simply a meeting of finance ministers and central bank governors, underwent a significant political climate change with the involvement of the government leaders. It is important that in the GFC the G20 became the key influential body - some attribute that to its broader membership and involvement of developing countries including the BRICS countries in its membership, and the ensuing increased credibility. The $\mathrm{G} 20$ used its assumed power to also rebrand the former Financial Stability Forum into the Financial Stability Board. The G20 itself is not a body created in the way that the IMF has been created - in fact, it includes the 19 countries with the largest GDPs, in the world, as well as the European Union, which is a member even though some EU member countries are individual G20 members. Spain, although not a member of the G20, traditionally attends all meetings, and based on the chairpersonship of the $\mathrm{G} 20$ and the venue of meetings, other countries are invited to join in in the meetings. Over the past 10 years, the FSB together with the IMF have performed peer reviews of all the G20 members, to measure their progress

\footnotetext{
56 See Rasmus, J. (2016), above n 54, p 15-16.

${ }^{57}$ See Berner, R. (2017), above $n 51$.

${ }^{58}$ Arner, D. W. (2007), p. 5. Arner noted that the system of international financial soft law based on nonbinding standards did not form a coherent system similar to the Bretton Woods system.
} 
against the agreed principles. The FSB similarly is not an international body with any formal character, but is influence is significant.

Notwithstanding the importance and effectiveness of international financial rules, they exist as soft law. Arner, already in 2007, pointed to the potential problems associated with the development of financial rules that are encapsulated in a preponderance of soft law, as this was a departure from the underlying rules-based system. Many of the internationally agreed rules are adopted voluntarily, and not through treaty obligations.

The Basel Accords are the prime example of transnational measures for financial stability that have been successfully adopted in many jurisdictions. Of course, the Basel Accords are not the only successful transnational regulatory framework adopted. Many of the principles espoused and promoted by IOSCO were also widely adopted. Likewise, international standards of auditing were issued by the International Federation of Accountants through the international Auditing and Assurance Standards Board and the work done by the International Association of Insurance Supervisors. Similarly, although its relevance to financial stability is more indirect, the FATF Anti-Money Laundering and Counter-Terrorism Financing framework has been implemented in many countries. ${ }^{59}$ The underlying reasons for the national adoption of these soft law instruments may have been commercial advancement, but the regulatory framework for financial stability internationally is rules-based. It could even be seen as a financial form of lex mercatoria.

Notwithstanding the benefits of globalisation, there are also some disadvantages. We will discuss the downside of globalisation below.

\section{Globalisation undermining financial stability: Solutions to financial instability become causes of financial instability}

1. The unwinding of the Washington Consensus and a globalisation backlash

Where globalisation was at first seen to be highly beneficial, it has also had some undesirable consequences. ${ }^{60}$ It has shifted production of goods to countries with lowest labour costs to the detriment of labour in the West. Some are worried that openness may not be fair. ${ }^{61}$ Notwithstanding the benefits of globalisation, it has also increased the complexity of, and sometimes added to, the volatility in financial markets. There are at least six different financial markets to consider: the money market, forex market, bond markets, derivatives markets, the stock market; and the over-the-counter market. Each of these has its own character and dynamic, and there are complex interconnections between them, as well as between them

\footnotetext{
${ }^{59}$ The FATF Recommendations have been widely adopted virtually worldwide. For implementation of the FATF recommendations, see the outcomes of the Mutual Evaluations Reports on the FATF website. FATF, (2019). ${ }^{60}$ El-Erian, M.A. (2017). He notes: 'The "great moderation," one that combined steady inclusive growth with financial stability, proved a short-term illusion'. Rodrik (above $n$ 49) argues that the current backlash is understandable: 'But the populist backlash has been on the rise for a while, for at least a decade or more ... More importantly, the backlash was perfectly predictable'.

${ }^{61}$ Berner (above $\mathrm{n}$ 51) agrees with European Central Bank President Mario Draghi, that openness should be fair, safe and equitable.
} 
and the real economy. These different markets also all play different roles in financial stability, and may be differently affected by financial instability.

The GFC undermined the certainties which seemed to underlie the Washington Consensus and led to increasing demands for protectionism. Ironically though, some of the seeds of the GFC lay in globalisation and the internationalisation of finance. The significance of the Bretton Woods system and later the so-called Washington Consensus - both of which collapsed should first be considered in the context of the rules-based nature of the global system underpinning the development of globalisation in the $20^{\text {th }}$ century.

\section{a) Bretton Woods}

Although the Bretton Woods system collapsed, and is sometimes seen only as a transitional stage to a new international monetary order, the Bretton Woods system was to a large extent a rules-based system, ${ }^{62}$ and nevertheless introduced a period of stability. After the World War, when international financial stability was of real concern ${ }^{63}$ the Bretton Woods agreements aimed, inter alia, at creating stability in the international financial sphere. ${ }^{64}$ 'The United States and the newly created International Monetary Fund were at the center (sic) of a system that sought to maintain that stability by linking exchange rates to the dollar, with the IMF the arbiter of any changes'. ${ }^{65}$ The legacy of the Bretton Woods system is that it serves as an example of successful international arrangements for international financial stability, based on multilateralism. ${ }^{66}$

The IMF, one of the key products of the Bretton Woods era, to a large extent became involved in international financial stability, even after its role as overseer of fixed exchange rates changed. ${ }^{67}$ The IMF morphed into a type of crisis manager, 'coordinating rescue operations that depended on IMF loans, country reform programs, and new money from the lending banks'. 68

It is important to note that the multilateral system was designed and adopted as a rules-based system. This was evidenced in the transformation of the former Soviet Union. 'Multilateralism

\footnotetext{
62 See Bordo, M (2017)

${ }^{63}$ See James, H. (2017).

${ }^{64}$ Fred Vinson, U.S. delegate, and future Supreme Court Chief Justice, in Commission I, seventh meeting, stated: 'The test of this conference is whether we can walk together, solve our economic problems, down the road to peace as we today march to victory. ... We must have cooperation, collaboration; utilize the machinery, the instrumentalities, that have been set up to provide succor to those who are hungry and ill; to set up, establish instrumentalities that will stabilize or tend toward stabilization of economies of our world'. See Schuler, K. and Rosenberg, A. (2013).

65 James, H. (2017), above n 63, p 5.

${ }^{66} \mathrm{lbid}, \mathrm{p} 6$. James notes that 'Multilateralism was inventive, though, in dealing with the new issues. The leading industrial countries in 1975 (France, Germany, Italy, Japan, United Kingdom, United States) convened at Rambouillet, France. It was the ancestor of modern Group of Seven (G7) summits, which added Canada in 1976 (and indirectly of the broader Group of 20) - and successfully dealt with inflationary developments and the political challenge that came when oil prices skyrocketed after the Organization of the Petroleum Exporting Countries cut production in 1973 following the Arab-Israeli war'.

67 See generally James, H., above $n 63$.

68 Ibid, p. 6.
} 
was also at the core of managing a cautious, rule-bound, and fundamentally orderly transformation of formerly state-planned (Soviet-style) economies in the 1990s'. ${ }^{69}$

During the 1990s however it became evident that apart from purely economic efforts, multilateral efforts also depended on the 'quality and effectiveness of government and the level of corruption and transparency'. ${ }^{70}$ The multilateral system was also challenged by the Asian crisis in $1997-98,{ }^{71}$ and the GFC. It can be considered to be currently under threat.

\section{b) The Washington Consensus}

The Washington Consensus has also to a large extent been discredited. The term Washington Consensus was used by John Williamson in $1989^{72}$ to collectively refer to the 10 policies that in his view more or less everyone in Washington (being the significant international institutions and the US Treasury) would agree were needed more or less everywhere in Latin America, ${ }^{73}$ i.e. in developing countries seeking support from developed economies. These policies therefore represented the loose consensus of the key international organisations at the time, and were promoted by the World Bank, IMF and OECD. The Washington Consensus was closely associated with globalisation, but also with financial stability in the context of economic stability.

The 10 principles of the Washington Consensus were: ${ }^{74}$

1. Fiscal discipline to reduce deficits and lower inflation;

2. Reordering of public expenditure priorities;

3. Reform of taxation to achieve a broad tax base with moderate marginal tax rates;

4. Liberalisation of interest rates to achieve and maintain financial instability;

5. Maintaining a competitive exchange rate;

6. Trade liberalisation;

7. Liberalisation of foreign direct investment;

8. Privatisation;

9. Deregulation; and

10. Promotion of property rights.

These principles were later heavily criticised, ${ }^{75}$ and have now been undermined somewhat by the GFC. Geopolitical shifts and the rise of China as an economic power have led to some describing the so-called 'Beijing Consensus', representing the policies that have led to the economic rise of China, as a replacement for the Washington Consensus. Some of the key criticisms of the Washington Consensus included that it favoured advanced economies and

\footnotetext{
69 Ibid, p. 6-7.

70 lbid, p. 7.

${ }^{71} \mathrm{lbid}$, p. 7: 'The outcome of the Asian crisis was interpreted widely in crisis countries, but also by some influential economists and theorists in the United States, as the imposition of US views and US interests.'

72 The term 'Washington Consensus' was coined in 1989 by John Williamson for purposes of a background paper. Although he summarised what he thought would be the 10 policies/principles that would be readily agreed to by everyone in Washington, they became a source of fierce ideological debate. See Williamson, J. (2004).

73 Farrar and Mayes, above n 40, p. 6.

${ }^{74}$ See Williamson, J. (2004), above $\mathrm{n} 72$.

75 See Broad, R. (2004).
} 
did not pay enough attention to development. ${ }^{76}$ Some of the 10 points contributed to financial stability but the aims of the 10 as a whole were broader and neoliberal. It can be argued that some of them, such as deregulation, may in fact have contributed to the GFC.

\section{The GFC and its aftermath}

Much has been written on the GFC 77 and how it arose out of the US Subprime mortgage crisis and policies of deregulation which had led to the expansion of derivatives and other forms of financial innovation such as securitisation. The crisis illustrated the extent of the overexpansion of the finance economy at the expense of the real economy or, as some put it, Wall Street over Main Street. With globalisation, contagion spread to other countries and other markets. In addressing the crisis, there was a significant role for central banks and ultimately the State. Indeed there was a need beyond the nation state - a need for international cooperation. This came through the $G 20$ and Financial Stability Forum which became the Financial Stability Board. There was a revitalisation of the IMF and the World Bank. This surge of international activity was later arrested by the unilateral actions of the USA and the UK in dealing with systemically important financial institutions and insolvency procedures and financial initiatives in the BRICS group of countries. Nevertheless work on Basel III resulted in agreement in 2010, although implementation has faltered.

Mark Jickling in a CRS Report for the US Congress on 9 April 2010 identified 26 causes of the GFC. ${ }^{78}$ This is the longest and most diverse list we have seen. Jickling summarises the arguments for and against each of these. Approximately half of these are connected with financial stability/instability.

We have discussed the GFC in detail elsewhere. ${ }^{79}$ Let us now consider the main steps taken to deal with the GFC and whether these have produced financial stability or instability. ${ }^{80}$

The first step was to purchase government debt and troubled assets from banks. This was a massive liquidity injection into the credit market. This was coupled with government guarantees of debt issued by the banks and purchase of preferred stock in banks. There were further bailouts of firms. Added to this has been the stimulus packages. All of this involves massive transfers of wealth from the State to the financial sector with little accountability. This has led, in effect, to subsidisation of financial capital rates of return and profitability,

\footnotetext{
${ }^{76}$ Farrar, J.H. and Parsons, L. (2012), p 373.

${ }^{77}$ For an interesting German view see Sim, H. (2011), Chapters 9-11.

78 Ibid.

79 See Farrar and Mayes (2013), above n 40; see also Farrar and Parsons, (2012), above n 76. These are: Imprudent mortgage lending; the housing bubble; global imbalances; securitisation; lack of transparency and accountability in mortgage finance; ratings agencies; mark-to-market accounting; deregulatory legislation; shadow banking system; non-bank runs; off-balance sheet finance; government mandated subprime lending; failure of risk management systems; financial innovations; complexity; human frailty; bad computer models; excessive leverage; relaxed regulation of leverage; credit default swaps (CDS); over-the-counter derivatives; fragmented regulation; no systemic risk regulator; short-term incentives; tail risk; and Black swan theory.

80 See Farrar and Parsons, (2012), above n 76.
} 
regardless of the need for a bailout. Excessive liquidity then drives the price of assets and subsidises banks and shadow banks. ${ }^{81}$

Regulatory reform was another important response to the GFC. Although there has been regulatory reform in the US, this is threatened by the Trump administration. Internationally, Basel 3 regulations require increased capital ratios, limits on leverage, narrow definitions of capital to exclude subordinated debt and new increased liquidity requirements.

The GFC has morphed into the Eurocrisis since 2009, ${ }^{82}$ requiring additional responses to new and different aspects of the financial crisis. Some of the EU members were directly affected by the GFC having been exposed to derivatives generated in the US subprime markets. Five of the member states Greece, Portugal, Ireland, Italy and Spain failed to generate enough growth to pay back bond holders. These were all in danger of default. The Eurozone member states created the European Financial Stability Facility to provide emergency lending to countries in difficulty. The European Central Bank made money available to provide credit to troubled banks. This has been criticised as kicking the can down the road. ${ }^{83}$ Interest rates have been slashed. At the same time EU countries continue to pursue austerity programs and export driven strategies to seek a growing share of already shrinking global exports and global trade economic pie.

These policies may ultimately prove ineffective. Low rates do not necessarily stimulate real investment. Austerity policies do not convince investors to commit new capital and export policies do not lift all boats but only some temporarily. ${ }^{84}$

There has been some debate as to which regulator is best placed to protect financial stability. The emerging consensus is that it should be the central bank, not just because of its flexibility with its balance sheet but also because its technical expertise. Many central banks have since the 1990s published financial stability reviews, even though their financial stability mandates may not always been express. ${ }^{85}$ There are, however, strong arguments that central banks being national institutions are not equipped to deal with the problem. They are losing control over the money supply and credit is now available globally. ${ }^{86}$ This makes supervision of the banking sector increasingly difficult.

While central banks can control short term interest rates, their ability to control long term interest rates is nil. ${ }^{87}$ They have been responsible for the massive injections of liquidity into financial systems but this has mainly been reactive to forces beyond their control. ${ }^{88}$ Central banks cannot stop financial asset bubbles and generally respond after the event. The current property bubble reveals their relative impotence. Central banks by definition cannot control

\footnotetext{
${ }^{81}$ See also Kolb, R. (2011), Chapter 8. See also Geithner, T. (2014), p. 369. For quantitative easing, see pp 3689.

82 See Mayes, D. (2013). See also Harvard University, (2014).

83 See Rhodes. D. and Stelter, D. (2011).

${ }^{84}$ Rasmus, J. (2016), above n 54, p. 137.

${ }^{85}$ For a comparison of different mandates of central banks to deal with financial stability, see Parsons, L. (2018).

${ }^{86}$ See Rasmus, J. (2016), above n 54, p 280 et seq.

87 Ibid, p. 281.

88 Ibid, p. 281.
} 
shadow banks. Only the regulators can do that and they have not done so. In their present role central banks contribute to government balance sheet fragility by the purchase of bad assets. $^{89}$

\section{The globalisation backlash: anti-globalisation, nationalism, and populism}

Recent times have seen a rise of nationalism, populism and anti-globalism. ${ }^{90}$ Nationalism and populism can be seen to be both reactions against globalisation. The very nature of globalisation is determinative: 'The same trade theory telling us that all countries participating in a free trade regime will be better off in the aggregate also tells you that not every individual in each country will be better off. The widely taught Heckscher-Ohlin trade model ... suggests that low-skilled workers in rich countries will lose out to similarly skilled workers in poor ones, which has in fact been happening in many industrialised countries with the rise of China, Mexico and other developing countries. ${ }^{91}$

There are many causes of the anti-globalisation movement. Much has changed since the Bretton Woods system, and the Washington Consensus. '... [T]oday exchange rates are largely set by market forces; the IMF has morphed into a combination of crisis manager, global economic monitor, and policy consultant; and US dominance may be replaced by new powers, such as China and the European Union, even as domestic political forces seem to be tugging the United States away from international engagement'. ${ }^{92}$

In this regard the year 2016 was a watershed moment. 'The United States and the United Kingdom were the main architects of the post-1945 order, with the creation of the United Nations systems, but they now appear to be pioneers in the reverse direction-steering an erratic, inconsistent, and domestically controversial course away from multilateralism' ${ }^{93}$ Both the United States and the United Kingdom, previously key actors in the international system and proponents of internationalisation and globalisation, experienced political changes that pushed them away from the globalisation agenda. In particular, in the US political changes have been described as 'populism' and in both the US and the UK concern for perceived national economic development and a protection of national priorities at the expense of larger international priorities. The decline in the US influence in the international order has been exacerbated by the Trump administration. ${ }^{94}$

The anti-globalisation and pro-nationalist sentiment has been triggered by those persons feeling left behind by the benefits of globalisation. This is evidenced by the widening gap

\footnotetext{
89 Ibid, p. 283.

${ }^{90}$ See Higgott, R. (2018), p. 2. Higgott notes: 'Particularly, recent trends in populism, nationalism, protectionism and regionalism are affecting international commitments to global public policy. They are also putting added pressure on the political and operational capacities of those global governance institutions created since the mid-twentieth century leading to several dangers to the stability of the contemporary political and economic orders ...'

${ }^{91}$ Fukuyama, F. (2018).

92 James, H. (2017) above n 63, p. 5.

93 Ibid.

${ }^{94}$ Higgott, R. (2018), above n 90, p. 4.
} 
between the wealthiest and the poorest. ${ }^{95}$ One of the underlying issues in anti-globalisation sentiments is financial disparity. Some of these issues pre-date the 2016 watershed moment. The Occupy Movement with the 'We are the 99 percent' slogan presented a strong presence in the aftermath of the GFC, ${ }^{96}$ when evidence of the high incomes of some of the worst culprits in the financial crisis became known. Improving the relationship between 'Wall Street' and 'Main Street' was a political priority, when the mistakes made in Wall Street was felt most in Main Street. Protests by disenfranchised (disillusioned) persons followed after a vast number of people who lost their homes in the sub-prime bubble, and in Europe austerity measures - partly linked to the GFC, and partly the consequence of EU membership, led to political unrest and extreme poverty (see Greece, Italy, Spain). At some point, 'Grexit' was even on the cards.

The income and wealth disparities were further highlighted by liberal immigration policies and the consequences of the middle-Eastern conflicts, resulting in an inflow of migrants in Europe. In fact, all over the world economic migrants are increasing in numbers. There is empirical evidence that suggests that there are significant welfare gains from international economic migration. ${ }^{97}$ Nevertheless, economic migrants are perceived as a threat to job and the welfare state. ${ }^{98}$

Nationalism and anti-globalism became part of the manifesto of Donald Trump and has led to the ironic result that Trump, ${ }^{99}$ as leader of the 'free world' and of the country that lent its face to globalisation, speaks against globalisation and the Chinese leader, Xi Jinping, speaks in favour of it. In a speech at the World Economic Forum in Davos in January 2017, Xi Jinping 100 argued positively about globalisation while recognising that it is a double-edged sword. He noted that it was necessary to steer the global economy out of difficulties and that growth had slowed down. He pointed out that there was inadequate global economic governance. Lack of growth made it difficult to meet people's expectations. He argued that we needed more driving forces for growth, and a well-coordinated, interconnected approach to cooperation. There must be a fair and equitable governance and a balanced development model. ${ }^{101}$

Most recently, in the preface to the 2019 Global Risks Report published by the World Economic Forum, Børge Bende, President of the WEF, declared: ${ }^{102}$

The world is facing a growing number of complex and interconnected challenges-from slowing global growth and persistent economic inequality to climate change, geopolitical tensions and the accelerating pace of the Fourth Industrial Revolution. In isolation, these are daunting challenges; faced simultaneously, we will struggle if we do not work together. There

\footnotetext{
${ }^{95}$ World Inequality Lab. (2018).

${ }^{96}$ See for example Krugman, P. (2011).

97 See Brunow, S., Nijkamp, P., \& Poot, J. (2015).

${ }^{98}$ See The Economist Special Report, (2016).

${ }^{99}$ See Frieden, J. (2018). Frieden considers the election of Donald Trump as 'by far the most important result of this backlash [against globalisation]'. On Trump as a populist, and what constitutes populism, see also

Friedman, U. (2017).

100 Jinping, X. (2017).

101 Ibid.

102 World Economic Forum, (2019).
} 
has never been a more pressing need for a collaborative and multistakeholder approach to shared global problems.

The Report points out that multilateralism is under threat, in particular multilateral dispute resolution. This has significant consequences for the status of law and regulation in the multilateral system: ${ }^{103}$

Political leaders have increasingly asserted the primacy of the nation-state in the international system and sought to weaken the constraints placed on national autonomy by international agreements and multilateral institutions. Defenders of multilateralism point out that this fragmentation risks creating blind spots, undermining global stability, and limiting the capacity to respond to cross-border challenges.

Further, the multilateral system can be weakened in many ways. ${ }^{104}$ For example, states can withdraw from agreements, block consensus or refuse to cooperate in international dispute resolution. ${ }^{105}$ Dispute resolution is crucial to the success of a multilateral system. There has however been increasing controversy over investor-state dispute settlement (ISDS) procedures. ${ }^{106}$ 'If cross-border trust is eroded by geopolitical competition and diverging values, creating mutually accepted dispute- settlement mechanisms may become increasingly complicated'. ${ }^{107}$

\section{A rules-based system replaced by deals-based agreements}

One of the key developments in the rise of nationalism and populism is the potential demise of the global 'rules-based' systems.

Rules-based orders have not always lasted - that was for example the case with the BrettonWoods System. 'Bretton Woods was short-lived, undone by both flaws in its basic structure and the unwillingness of key sovereign members to follow its rules'. ${ }^{108}$ Peel and Ungerer point out that 'there is a broad consensus in the western world that the rules-based order that has governed international relations for the past 70 years is under unprecedented strain. There is less agreement on where the most serious threats are coming from, how fundamental they may prove, and how to deal with them'. ${ }^{109}$ Trump with his 'America First' policy, the handling of the refugee crisis and the invasion of Crimea all erode respect for a rules-based system. ${ }^{110}$

\section{Threats to financial stability and financial stability regulatory frameworks}

\footnotetext{
${ }^{103}$ World Economic Forum, (2019), p 24.

${ }^{104}$ Ibid, p 23 et seq.

105 Ibid, p 23 et seq.

106 Ibid.

107 Ibid.

108 See Bordo, M (2017).

${ }^{109}$ See Peel, Q. (2018), p. 3.

${ }^{110}$ See Shetler-Jones P. (2017).
} 
The following threats to financial stability and financial stability legal frameworks that relate back directly to problems associated with globalisation can be identified.

\section{Disruptions in the international trade system}

One of the significant consequences of the nationalist or protectionist backlash against globalisation is the withdrawal by nation states from existing trade agreements, and the undermining of the current trade dispute resolution system. Trade protectionism has risen, with Russia, India and the US implementing more than 500 discriminatory trade practices since 2009. ${ }^{111}$ This can be seen as evidence of the end of globalisation: 'Evidence of the end of globalisation and greater integration is mounting. Growth in trade and cross-border investment which has underpinned prosperity and development is being reversed' ${ }^{112}$ The consequences are that conditions of financial instability can be created, especially through the escalation of trade disputes into 'trade wars'. The IMF in the 2018 Global Report on Financial Stability warns: ${ }^{113}$

A broader escalation of trade actions may undermine investor confidence, harming the economic expansion. Political and policy uncertainty (for example, in the event of a no-deal Brexit or the reemergence of concerns about fiscal policy in some highly indebted euro area countries) could adversely affect market sentiment and lead to a spike in risk aversion.

Difficulties may arise if cross-border disputes arising under a previous legal dispensation has to be resolved in a different legal dispensation, perhaps one in which the norms and principles of the applicable legal systems are different.

\section{Nationalism leading to a disregard for international interests in financial matters especially policy normalisation}

The normalisation of monetary policy and an adjustment of interest rates in key jurisdictions can have severe knock-on effects in other jurisdictions. Monetary policy normalisation is a direct consequence of the GFC, a financial crisis facilitated by the internationalisation of finance and globalisation. Following the GFC, balance sheets of central banks have expanded dramatically and interest rates have been low. '[N]ormalisation of interest rates and liquidity conditions may well expose other weaknesses in the global financial system: as Warren Buffet once put it, only when the tide goes out do you discover who's been swimming naked. ${ }^{114}$ Financial stress can be spread in an unforeseen manner because global financial institutions are so closely linked. ${ }^{115}$ Further 'there may be precious little time to adjust to higher interest rates and exchange rate volatility, as mobile international capital can be highly procyclical'. ${ }^{116}$

\footnotetext{
111 See Bhattacharya, A., Khanna, D., Schweizer, C and Bijapurkar, A. (2017).

112 Das, S. (2013).

${ }^{113}$ See International Monetary Fund (2018).

${ }^{114}$ See Carstens, A. (2017). See also International Monetary Fund (2018), warning that spill overs from the policy normalization in advanced economics can have a negative impact on emerging market economies. The IMF expressed concern that policy normalisation may increase, leading to a rise in interest rates, but that market participants appeared 'complacent about the risk of a sharp tightening of financial conditions'.

115 Ibid.

116 Ibid.
} 
When concerns for international financial stability are completely outweighed by nationalist concerns, the international system which has relied on cooperation and collaboration to ensure international financial stability, can be disrupted. For example, in the aftermath of the GFC central banks undertook joint policy actions in order to have a positive outcome for international financial stability. A disregard of international financial stability considerations in light of nationalist concerns can have dire consequences for international financial stability. Similarly, a demonstration of withdrawal from international 'agendas' set by the $\mathrm{G} 20$ and the FSB, even if these are only manifested as 'soft law', will demonstrate a concerning departure from the international 'rules-based order'.

The importance of observing international standards in financial matters cannot be overemphasised. The nature of international financial standards are different from standards, for example, relating to traffic rules, or the shape and size of electricity outlets, which are easily overcome and have minor actual cross border impact. ${ }^{117}$ In fact, international financial standards are seen as being 'a public good'118 that provides 'great benefit'. ${ }^{119}$ Countries, including Australia, benefit from adhering to international standards, and from others also adhering to those international standards. ${ }^{120}$

\section{Dismantling of or withdrawal from existing rules-based systems for nationalist/protectionist purposes}

The withdrawal from existing rules-based systems ${ }^{121}$ for nationalist/protectionist purposes come with real risk to financial stability and financial stability regulatory frameworks. Examples include the withdrawal from regional unions (Brexit), potentially without an agreement to facilitate the orderly withdrawal. ${ }^{122}$

Central clearinghouses pose a particular benefit - and risk. After the GFC the use of Central Counterparty Clearing (CCPs) was strongly promoted because of the increased transparency and clarity brought into the system. But '[c]entral clearing creates a single point of

\footnotetext{
117 See Byres, W. (2017).

118 Ibid. Byres noted: 'the maintenance of genuinely international financial markets, facilitated by internationally-active financial institutions providing essential support for trade and commerce, is still firmly seen as an important prerequisite for economic growth and well-being. International financial standards help to make this happen'.

119 Ibid.

${ }^{120}$ Ibid. Byres noted: 'We also see others' adherence to standards as being of benefit to us. Over the past couple of decades, Australia has sought to have a financial system that is open to foreign competitors - many of whom have brought a strong competitive impetus, not to mention a healthy degree of innovation, to the benefit of the Australian community. Adherence to well-established international standards by those foreignowned participants allows us to place a much greater degree of (although not total) reliance on home country prudential requirements, and correspondingly less need for duplicative or restrictive domestic regulation, than might otherwise be the case'.

${ }^{121}$ The existing system is based on rules-based agreements such as GATT, WTO, NAFTA, and NATO. The G7 and G20 were bodies that were created to promote cooperation. See Fukuyama, F. (2018a)

122 The Bank of England has for example warned that some derivative contracts could be illegal in a 'no-deal Brexit', and has highlighted the risks posed for central clearing houses that take on the default risk of participants. Bank of England, (2018).
} 
vulnerability for the failure of the system - the CCP - that must be resilient and managed carefully'. ${ }^{123}$

In international trade, there has been a noticeable trend favouring bilateral agreements over multilateral agreements that protect national interests more. ${ }^{124}$ Changes to regional agreements affect trade, finance and commerce generally. Similarly, withdrawal from foreign investment agreements and/or dispute resolution agreements can create conditions of financial instability. For example, a withdrawal from the ICSID treaty in full could render foreign investors open to applicable national law, instead of international law adjudicated in an international arbitration forum. In these areas too, the risks flow from cross-border disputes originating from a previous dispensation that have to be resolved in a new, different legal dispensation, perhaps even in a contractual vacuum.

\section{Nationalism leading to a disregard for international interest in global} issues with possible financial consequences, e.g. climate change and technology

A lack of cooperation between countries on pressing global issues such as climate change, can lead to financial instability. The World Economic Forum considers the impact of climate change to be severe, and the lack of collaborative effort by countries potentially disastrous. It has accused the world of sleepwalking into disaster. ${ }^{125}$ The withdrawal by a large economy such as the US from climate change treaties demonstrates protectionism and a disregard for the need to collaboratively resolve global issues.

Rapid technological developments also constitute a threat. Digital connectedness has been described as the new face or new version of globalisation: ${ }^{126}$

While the world is becoming more decentralized politically and physically, customers, devices, services, processes, and businesses continue to integrate digitally. The simultaneous rise of economic nationalism and of digital integration is redefining the economic, business, and political framework that has shaped our understanding of globalization for the past half century, ushering in a radically new model.

Rapid technological developments, including increases in digital industries, services and platforms, ${ }^{127}$ however pose an important risk for financial stability. ${ }^{128}$ The consequences of globalisation and the worldwide access to the internet is that instability introduced as a consequence of technological developments could spread quickly. True border-less (or barrier-less) products such as cryptocurrencies would potentially be one of the main contributors. One of the key risks factors for financial stability is however that cyber capabilities can exaggerate a crisis that is already underway, or can initiate a crisis. ${ }^{129}$ Cyber

\footnotetext{
${ }^{123}$ Berner, R. (2017) above $\mathrm{n}$ 51. Berner points out that 'the liquidity demands and potential procyclicality of intraday margining practices - and the interconnectedness of CCPs, their clearing members, providers of custodial, credit, and especially liquidity services - means that even those less-highly connected CCPs and their clearing members may be affected by or can transmit or amplify shocks to the network'.

${ }^{124}$ See Bhattacharya, A., Khanna, D., Schweizer, C and Bijapurkar, A. (2017), above $n 111$.

${ }^{125}$ Collins, A. (2019), above $n 11$.

${ }^{126}$ See Bhattacharya, A., Khanna, D., Schweizer, C and Bijapurkar, A. (2017), above n 111.

127 Ibid.

${ }^{128}$ See Carstens, A. (2017), above $\mathrm{n} 114$.

${ }^{129}$ Healey, J., Mosser, P., Rosen, K. \& Tache, A. (2018).
} 
attacks can have significant consequences. Cyber attacks are different in respect of the intentions behind them and their timing, and are therefore different from traditional financial and policy shocks. in both intent and timing. ${ }^{130}$ No cyber attacks have as yet resulted in financial instability, ${ }^{131}$ but 'the potential impact of a carefully timed cyber attack designed to exploit the (negative) dynamics associated with traditional financial contagion channels has been insufficiently examined.' ${ }^{\prime 32}$

The preservation of a rules-based framework may be essential in preventing financial crises.

5. Protectionism manifesting as a disregard for soft law instruments and agreement

General scepticism towards global agreements and standards as a consequence of sovereignism and protectionism - for example a reluctance to continue to operate under the Basel Accords and/or the principles of the FATF - can have unknown and destabilising effects in financial markets. For example, a lack of commensurability in national legislation on the failure of financial institutions, could further complicate the unravelling of complex international financial institutions in the event of insolvency. It will remain to be see the extent to which commercial common sense and mercantile principles will and override political choices.

Soft law systems - which have served the world well as part of globalisation - may be less effective. Much of the 'rules-based' order underpinning international financial stability is, however, founded in soft law and a desire for harmonisation that increased certainty. A decline in the willingness of states to be bound by soft law in finance may lead to a loss of international cooperation and commensurability in financial rules and standards. Although the semi-autonomous world of banking and finance is characterised by an inherent pragmatism and strong regard for commercial realities, it may be under threat if a rules-based order falls away. With less harmonisation, and a possible break down of the system, there will be less certainty in cross-border transactions and disputes, and greater prospects of financial risks.

It is becoming more difficult to reach agreement between international participants, and consensus is more difficult to reach. That has an important impact on international financial standards that have been built on consensus: ${ }^{133}$

In the immediate aftermath of the crisis, consensus on international standards was much easier: the problem was obvious, national and international interests were highly aligned, and big broad brush responses were the order of the day. Now, we are asking more subtle and nuanced questions about the design of the framework, its impacts and its incentives. That the answers to these questions are less obvious than the ones we were answering in 2009 and 2010 is unsurprising.

\footnotetext{
${ }^{130} \mathrm{Ibid}$.

131 Ibid.

132 Ibid.

${ }^{133}$ Byres, W. (2017), above $n 117$.
} 


\section{Conclusion}

Moving to a deals-based order comes with risks. 'Firstly, it means the world may be heading for a more volatile period when international relations will be more dynamic and less predictable, and relationships more fragile'. ${ }^{134}$ Further, a deals-based order 'may entrench or deepen inequality among nation states, because of the way deals allow more powerful parties to exploit a weaker counterpart'. ${ }^{135}$ The demise of the rules-based order also poses risks for financial stability because it has the potential to affect the regulatory framework for financial stability.

This paper concludes that globalisation has had both a positive and a negative impact. Although globalisation coincided with the internationalization of finance, and with the accompanying internationalization of the legal framework with significant advantages and benefits, it posed both solutions and threats to financial issues. The GFC led to greater criticism of globalisation and doubts about the western model on which current thinking was based. There was increasing emphasis on the state and state capitalism. The Chinese experience seemed to adduce strong evidence in support of this as a rival model. The unravelling of globalisation through nationalism and populism threatens financial stability and the legal frameworks for the protection of financial stability. What may be needed is an adjustment, or a 'reboot'. Higgott suggests: 'It might be more fruitful trying to re-boot a cooperative rules-based order recognising that rules need to be reformed in order to secure continued adherence from the members of that order. A rules-based order must be shown to work for all'. ${ }^{136}$

This does not mean converting everyone to a single model of governance. It means that we have to respect differences and aim to achieve a minimal order that can accommodate that diversity, but prevent financial instability. This requires legitimacy, equity and continuing relevance of the rules and the likelihood of their acceptance and enforcement. ${ }^{137}$ Replacing a rules-based order with a deals-based order is contrary to the interests of Australia and the $\mathrm{EU}$, and ultimately contrary to a rational view of the long-term interests of the USA.

\section{References:}

Al-Rodhan, Nayef R.F. (2006). Definitions of Globalization: A Comprehensive Overview and a Proposed Definition, 19 June 2006. Retrieved from

http://citeseerx.ist.psu.edu/viewdoc/download?doi=10.1.1.472.4772\&rep=rep1\&type=pdf.

Allen, Hilary J. (2014) 'What is 'financial stability'? The need for some common language in international financial regulation' Georgetown Journal of International Law (45), pp. 929-

\footnotetext{
${ }^{134}$ Shetler-Jones, above n 110

135 Ibid.

${ }^{136}$ Higgott, R. (2018), above n 90, p. 20.

${ }^{137}$ For a discussion of the problems related to legitimacy and equity, see The Royal Institute of International Affairs, (2015).
} 
Allen, W.A. and Wood, G. (2006). Defining and achieving financial stability. Journal of Financial Stability, 2, pp. 152 -.

Arner, D. W. (2007) Financial Stability, Economic Growth, and the Role of Law. Cambridge: Cambridge University Press.

Arthurs, H. (2009) Law and Learning in an Era of Globalisation. German Law Journal 10(7) pp 629-639.

Austin, J.L. (1962) Sense and Sensibilia. (Reconstructed from the manuscript notes by G.J. Warnock). London: Oxford University Press http://selfpace.uconn.edu/class/percep/AustinChs1-6.pdf.

Bank of England (2018) Consultation Paper 26/18 - UK withdrawal from the EU: changes to PRA Rulebook and onshored BTS (CP26/18). Retrieved from https://www.bankofengland.co.uk/-/media/boe/files/prudential-regulation/consultationpaper/2018/cp2618-complete.

Berner, R. (2017, 2 November) Globalization and Financial Stability. (Remarks at the IMF 18th Jacques Polak Annual Research Conference, 2 November 2017, Washington DC). Retrieved from https://www.google.com/search?client=safari\&rls=en\&q=Berner,+R.+(2017,+2+November) +Globalization+and+Financial+Stability.+(Remarks+at+the+IMF+18th+Jacques+Polak+Annua I+Research+Conference,+2+November+2017,+Washington+DC).\&ie=UTF-8\&oe=UTF-8.

Berner, R. (2017, 2 November). Globalization and Financial Stability. (Speech: Remarks at the IMF 18th Jacques Polak Annual Research Conference, 2 November 2017, Washington DC). Retrieved from https://www.financialresearch.gov/public-appearances/files/BernerRemarks_IMF-18th-Jacques-Polak_11-02-2017.pdf.

Bhattacharya, A., Khanna, D., Schweizer, C and Bijapurkar, A. (2017). Going Beyond the Rhetoric. (BCG Henderson Institute). Retrieved from https://www.bcg.com/enau/publications/2017/new-globalization-going-beyond-rhetoric.aspx.

Broad, R. (2004). The Washington consensus meets the global backlash: shifting debates and policies. Globalizations, 1(2), pp 129-154.

Brunow, S., Nijkamp, P., \& Poot, J. (2015). The impact of international migration on economic growth in the global economy. In Chiswick, B.R., and Miller, P.W. (eds) Handbook of the Economics of International Migration, Vol. 1, pp. 1027-1075. Elsevier Science B.V..

Byres, W. (2017). International standards and national interests. (The American Chamber of Commerce in Australia Business Briefing, Sydney, 28 June 2017). Retrieved from https://www.apra.gov.au/media-centre/speeches/international-standards-and-nationalinterests. 
Carstens, A. (2017) The nature of evolving risks to financial stability (Keynote address, 53rd SEACEN Governors' Conference/High-level Seminar and 37th Meeting of the SEACEN Board of Governors, Bangkok, 15 December 2017). Retrieved from https://www.bis.org/speeches/sp180214.htm.

Claessens, S. and Ayhan Kose, M. (2017, November). Asset prices and microeconomic outcomes: a survey. (BIS Working Papers No 676). Retrieved from https://www.bis.org/publ/work676.pdf

Chong, V. (2016, 15 September). If not for peace, why does Australia favour rules-based order? The Mandarin. Retrieved from https://www.themandarin.com.au/70225-rulesbased-global-order-australian-shift/.

Collins, A. (2019). Are we sleep-walking into a new global crisis? Retrieved from https://www.weforum.org/agenda/2019/01/is-the-world-sleepwalking-into-a-new-globalcrisis/.

Cordella, T. and Ospino Rojas, A. (2017). Financial globalization and market volatility: an empirical appraisal (English). Policy Research working paper; no. WPS 8091. Washington, D.C. : World Bank Group. Retrieved from http://documents.worldbank.org/curated/en/720931496861776485/Financialglobalization-and-market-volatility-an-empirical-appraisal.

Cox, M. (2017). The rise of populism and the crisis of globalisation: Brexit, Trump and beyond. Irish Studies in International Affairs, (28). pp. 9-17.

Cox, Michael. (2018, February). Understanding the global Rise of Populism. (LSE Ideas, Strategic Update). Retrieved from http://www.Ise.ac.uk/ideas/research/updates/populism.

Das, S. (2013, 1 October). The new economic nationalism. The Drum. Retrieved from https://www.abc.net.au/news/2013-09-30/das-the-new-economic-nationalism/4988690.

El-Erian, M.A. (2017). The Future of Economic and Financial Globalization. Journal of international Affairs, Columbia, SIPA (Web Article). Retrieved from https://jia.sipa.columbia.edu/future-economic-and-financial-globalization.

Farrar, J.H. and Parsons, L. (2012) Globalisation, the Global Financial Crisis and the Reinvention of the State. Singapore Academy of Law Journal, (24) 367.

Farrar, J.H. and Mayes, D. (2013). Globalisation, the crisis and the state: Introduction, in John H Farrar and David Mayes (eds), Globalisation, the Global Financial Crisis, and the Reinvention of the State (Cheltenham, UK, Northampton, MA, USA, Edgar Elgar) 1.

Farrar, J.H. and Parsons, L. (2018). Globalisation and Financial Instability, Conference in honour of Prof David Mayes, Auckland University New Zealand, April 2018. 
FATF (2019) Mutual Evaluations. Retrieved from http://www.fatf-

gafi.org/publications/mutualevaluations/?hf=10\&b=0\&s=desc(fatf_releasedate).

FATF, FATF Recommendations (2012) (Webpage, FATF, 2019). Retrieved from http://www.fatf-gafi.org/publications/fatfrecommendations/documents/fatfrecommendations.html.

Frankopan, P. (2015). The Silk Roads. (London: Bloomsbury Publishers).

Frieden, J. (2018). The backlash against globalization and the future of the international economic order. Retrieved from https://scholar.harvard.edu/files/jfrieden/files/frieden_future_feb2018.pdf.

Friedman, U. (2017, 27 February). What Is a Populist? And is Donald Trump one?. The Atlantic, Retrieved from https://www.theatlantic.com/international/archive/2017/02/whatis-populist-trump/516525/.

Fukuyama, F. (2018). Why Populism? The Populist Surge. Retrieved from https://www.theamerican-interest.com/2018/02/09/the-populist-surge/.

Fukuyama, F. (2018a, 6 February). Opinion: How to tame the populists. Australian Financial Review.

Funke, M and Trebesch, C. (2017, December) Financial Crises and the Populist Right. ifo DICE Report, 15(4). Retrieved from https://www.cesifo-group.de/DocDL/dice-report-2017-4funke-trebesch-december.pdf

Funke, M. and Trebesch, C. (2017). Financial Crises and The Populist Right. ifo DICE Report 4, Volume 15(December) Retrieved from https://www.cesifogroup.de/DocDL/dice-report2017-4-funke-trebesch-december.pdf

Geithner, T. (2014). Stress Test: Reflections on Financial Crises. London: Random House. Goodhart, C.A.E. (2010) The Changing Role of Central Banks (LSE Financial Markets Group Paper Series, Special Paper 197 December 2010). Retrieved from http://www.Ise.ac.uk/fmg/assets/documents/papers/special-papers/SP197.pdf

Hale, T. and Held, D. (2017, 29 November) Why is the anti-global backlash happening now? (World Economic Forum) Retrieved from https://www.weforum.org/agenda/2017/11/antiglobalization-brexit-backlash-nationalism-control/.

Harvard University. (2014). The European Financial Crisis: Analysis and a Novel Intervention. Retrieved from https://scholar.harvard.edu/files/markesposito/files/eurocrisis.pdf.

Healey, J., Mosser, P., Rosen, K. \& Tache, A. (2018, October). The Future of Financial Stability and Cyber Risk. (The Brookings Institution, School of International and Public Affairs, Columbia University). Retrieved from https://www.brookings.edu/research/the-future-offinancial-stability-and-cyber-risk/ 
Higgott, R. (2018) Globalism, Populism and the Limits of Global Economic Governance. Journal of Inter-Regional Studies: Regional and Global Perspectives, 1, p 2-23.

International Monetary Fund (2018). Global Financial Stability Report - A decade after the Financial Crisis: Are we safer?. Retrieved from https://www.imf.org/en/Publications/GFSR/Issues/2018/09/25/Global-Financial-StabilityReport-October-2018.

James, H. (2017). Bretton Woods to Brexit, Finance and Development, 54(3), pp 4-9.

Jinping, X. (2017). Full Text of Xi Jinping keynote at the World Economic Forum. Retrieved from https://america.cgtn.com/2017/01/17/full-text-of-xi-jinping-keynote-at-the-worldeconomic-forum.

Kolb, R. (2011). The Financial Crisis of Our Time. New York: Oxford University Press. Krugman, P. (2011, 24 November). We are the 99.9\%. The New York Times, Retrieved from https://www.nytimes.com/2011/11/25/opinion/we-are-the-99-9.html

Laker, J.F. (1999) Monitoring Financial System Stability. Reserve Bank of Australia Bulletin, October 1999.

Lupo-Pasini, Frederico (2017). Financial Nationalism and International Financial Law (14 November 2017, University of Oxford Faculty of Law Blog). Retrieved from https://www.law.ox.ac.uk/business-law-blog/blog/2017/11/financial-nationalism-andinternational-financial-law.

Mayes, D.G. (2013) The Euro Crisis. In John H Farrar and David Mayes (eds), Globalisation, the Global Financial Crisis, and the Reinvention of the State (Cheltenham, UK, Northampton, MA, USA, Edgar Elgar) 243-271.

Michael Bordo (2017, 23 April). The operation and demise of the Bretton Woods system: 1958 to 1971. (VOX CEPR Policy Portal). Retrieved from https://voxeu.org/article/operationand-demise-bretton-woods-system.

Minsky, Hyman (1986). Stabilising an Unstable Economy, Yale University Press New Haven 1986.

Obstfeld, M. (2015, January). Trilemmas and trade offs living with financial globalisation. (BIS Working Papers No 450 Jan 2015). Retrieved from https://www.bis.org/publ/work480.pdf.

Parsons, L. (2018). Domestic regulatory architecture for the protection of financial stability after the GFC: Global order or disorder', in Ireland-Piper, D. and Wolff, L (eds), Global governance and regulation: Order and disorder in the 21st century (Abingdon-on-Thames, UK, Routledge) 
Peel, Q. (2018). Threats to a Rules-Based International Order, in Peel, Q \& Ungerer, C. (eds) EU-Australia Leadership Forum Sectoral Policy Workshop: Rules-Based International Order: Background Papers 23 April 2018. Retrieved from https://www.europeaustraliaforum.eu/sites/default/files/SPW_Background_Papers_RBIO.p df.

Productivity Commission (2018, 7 February). Draft Report on Competition in the Australian Financial System. Retrieved from https://www.pc.gov.au/inquiries/completed/financialsystem\#report.

Rasmus, J. (2016). Systemic Fragility in the Global Economy. Atlanta, Georgia: Clarity Press Inc..

Reserve Bank of Australia (2019) Financial stability. Retrieved from https://www.rba.gov.au/fin-stability/.

Rhodes, D. and Stelter, D. (2011, August). Collateral Damage: Stop Kicking the Can Down the Road. (The Boston Consulting Group). Retrieved from https://www.bcg.com/documents/file83753.pdf.

Rodrik, D. (2018). Populism and the economics of globalization. Journal of International Business Policy, 1-22.

Roubini, N. (2014, June 2). Economic insecurity and the rise of nationalism. The Guardian, Retrieved from newspaper homepage https://www.theguardian.com/business/economicsblog/2014/jun/02/economic-insecurity-nationalism-on-the-rise-globalisation-nourielroubini

Schinasi, G.J. (2004). Defining financial stability. (Working Paper No 04/187). Retrieved from https://www.imf.org/en/Publications/WP/Issues/2016/12/31/Defining-Financial-Stability17740.

Schinasi, G.J. (2010) Defining Financial Stability and Establishing a Framework to Safeguard It. In Alfaro, R. (ed) Financial Stability, Monetary Policy and Central Banking, Central Bank of Chile.

Schuler, K. and Rosenberg, A. (eds) (2013) The Bretton Woods Transcripts. New York, New York: Centre for Financial Stability.

Shetler-Jones, P. (2017, 8 September). Welcome to the new deal-based order. (World Economic Forum). Retrieved from https://www.weforum.org/agenda/2017/09/welcome-tothe-new-deal-based-order/.

Sim, H. (2011). Casino Capitalism - How The Financial Crisis Came about and What Needs to Be Done Now Oxford, Oxford University Press. 
Smaga, P. (2013). Assessing Involvement of Central Banks in Financial Stability (Policy Paper, 23 May 2013, Centre for Financial Stability). Retrieved from

http://www.centerforfinancialstability.org/research/Assessing_052313.pdf.

The Economist Special Report, (2016, 29 September). Needed but not wanted. The Economist, Retrieved from https://www.economist.com/specialreport/2016/09/29/needed-but-not-wanted.

The Royal Institute of International Affairs. (2015). Challenges to the Rules-Based International Order/ (Background Paper to Session One, The Search for Global Leadership, Chatham House, The London Conference). Retrieved from

https://www.chathamhouse.org/sites/default/files/media_wysiwyg/London\%20Conference \%202015\%20-\%20Background\%20Paper\%20-\%20Session\%200ne.pdf.

Tissot, B. (2016). Globalisation and financial stability risks: is the residence-based approach of the national accounts old-fashioned?. (BIS Working Papers No 587 October 2016) Retrieved from https://www.bis.org/publ/work587.htm.

UNESCO. (2017). Globalisation. Retrieved from http://www.unesco.org/new/en/social-andhuman-sciences/themes/international-migration/glossary/globalisation/.

Ungerer, C. (2018). Whose Rules? In Which Order?, in Peel, Q and Ungerer, C. Background papers prepared for the EU-Australia Leadership Forum Sectoral Policy Workshop on a RulesBased International Order, EU-Australia Leadership Forum, Sectoral Policy Workshop: RulesBased International Order, 23 April 2018, p 11.

Williamson, J. (2004, 24-25 September). A Short History of the Washington Consensus. (Paper commissioned by Fundación CIDOB for a conference "From the Washington Consensus towards a new Global Governance," Barcelona, September 24-25, 2004). Retrieved from https://piie.com/publications/papers/williamson0904-2.pdf.

World Economic Forum. (2018). Global Risks Report 2018, $13^{\text {th }}$ edition. Retrieved from https://www.weforum.org/reports/the-global-risks-report-2018

World Economic Forum. (2019). Global Risks Report 2019, $14^{\text {th }}$ edition. Retrieved from https://www.weforum.org/reports/the-global-risks-report-2019

World Inequality Lab. (2018). World Inequality Report. Retrieved from https://wir2018.wid.world 